\title{
Embodying Equivocations: Ecopolitical Mim licries of Climate Science and Shamanism
}

\author{
Aníbal Arregui \\ University of Vienna/ CEFRES-Charles University
}

\begin{abstract}
This article proposes a non-recursive detour for the perspectival concept of 'equivocation' by applying it to an ongoing ecopolitical approximation. I will describe how a Brazilian climatologist and a Yanomami shaman translate their concerns about the Amazonian rainforest in order to reach each other's audiences. Drawing on their public appearances and published texts, it will be argued that they mimetically rephrase their environmental thinking according to - what they assume to bethe conceptual imagination and the formats of communication of the Other. The shaman's and the scientist's connective gestures are thus taken as part of an exceptional form of public, ecopolitical dialog, concerned with the future of the rainforest. Whereas the concept of 'equivocation' has proven useful to disclose the translational-ontological gap between the native's and the very ethnographer's conceptual languages, this article aims at looking somewhere-else than the recursive, ethnographic Self. In particular, the argument will pay attention to how equivocations and the so-called 'ontological differences' might be embodied by specific actors, in specific situations, inviting us to describe how these differences are de facto navigated and co-implicated by other people than anthropologists.
\end{abstract}

Key words: Climate Science, Shamanism, Body, Ecopolitics, Amazonia.

It has been argued that recent anthropological approaches that appear to endorse notions of ontological incommensurability between cultures or peoples are alarmingly ill-equipped to confront the common crises we all face, such as climate change. The appeal to common threats and collective solutions is particularly obvious in political contexts outside academia, but it is also present in anthropological reflections on itself, especially in the critiques of the ontological turn and its apparent failure to provide a politically tangible account for global forms of domination and 
current environmental crises (see Vigh and Sausadal, 2014; Bessire and Bond, 2014; Fortun, 2014; Hornborg, 2015).

In this paper I engage such debate by first presenting the following observation: I argue that the idea of 'incommensurability' has been imputed to some currents of the ontological turn (overview in Hazarika, 2016), yet it is not a flagship concept of their proponents. In fact, one of the

most discussed authors within the ontological turn tradition, Eduardo Viveiros de Castro, has explicitly distanced himself from the idea of incommensurability if this is seen as short-circuiting cultural translation and ontological 'inter-intelligibility' (2010: 330) ${ }^{1}$. The notion of incommensurability was first employed in post-positivist philosophy, most famously by Kuhn (1962) and Feyerabend (1962), to address the conceptual incompatibility between scientific theories, and the impossibility of detaching the empirical realities described from the theories that outlined them. Kuhn argued for the untranslatability between scientific theories, proposing that hermeneutics in the history of science is not about 'translation' but about becoming 'bilingual', that is: about learning how to keep separated two irreconciliable theoretical languages (2000:94).

Despite the apparent resemblance with the comparative proposal of ontological theories, the problem of incommensurability has a very different nuance in anthropology, because comparison here is not between scientific theories but between cultures or peoples. The sheer extrapolation of post-positivist terms to anthropology, without further contextualization, would place 'our' notion of incommensurability onto the sensitive domain of reified differences according to ethnic or geographic criteria. This, I would argue, is far from being the goal of the ontological theories I will focus on. In fact, comparison and translation are at the core of the ontological turn's project, so the notion of a culturally, ethnically or geographically pre-given incommensurability of relational worlds can be rather seen as a straw man that courts more misunderstandings than productive discussions within the discipline.

${ }^{1}$ „None of this implies incommensurability as a necessary premise or final outcome. It implies reciprocal unintelligibility even less. Amerindian perspectivism itself, like the recursive experiment that I made from it, deals precisely with the problem of commensuration as an activity of how to make what happens in a world correspond to what happens in another world. Not only do these worlds intersect in diverse dimensions, but also it is always possible to trace echoes and inter-intelligibilities (....". (Viveiros de Castro, 2010b: 330) 
This is why instead of focusing on incommensurability as understood in post-positivst philosophy, I propose to focus the critique on the concept of 'equivocation' (Viveiros de Castro , 2004), which plays a more explicit role in hard-liner ontological currents, often identified as 'recursive' (see Salmond 2013) or methodologically 'self-reflexive' (Holbraad, Pedersen and Viveiros de Castro, 2014). 'Equivocation', as I will explain bellow, is the gap of knowledge that an ethnographer has to accept and 'control' when comparing between two relational ,worlds' or 'ontologies'2 such as 'naturalism' and 'perspectivist' animism (Ibid). Equivocation is a recursive tool because it reveals the inability of an observer to find perfect conceptual equivalents between the ontological sets she is trying to compare, precisely because the observer's thought is part of (or colonized by) one of the poles of comparison. So the emphasis of the 'equivocation' is not on a previously given incommensurability of two worlds that an ethnographer observes, but on the lack of absolute conceptual correspondence that the anthropologist needs to disclose when translating between her world or ontology and the world of others. If incommensurability implies untranslatability, equivocation restores the possibility and the need of translation (an inescapable corollary of our discipline) by developing a self-reflexive anthropology that looks at its own comparative limitations and extracts its knowledge from them.

This essay, however, proposes a different analytical move to make some possibilities of translation more crystalline and avoid any presuppositions of incommensurability-asuntranslatability. In particular, the article will argue for a non-recursive detour in the way the ontological-perspectival theories draw upon the notion of equivocation. It does so by focusing on a particular case where cross-cultural translations are being produced by other people than anthropologists. In particular, I will present some of the public gestures that two spokespersons, a climatologist and a shaman, have performed in the last years in order to reach beyond their usual audiences. These experimental and connective gestures will be first addressed as 'mimicries', which

2 Note that I am using here the conceptual vocabulary of the ontological turn, where the notion of „ontological difference“ often denotes a difference of „world“ (e.g. Viveiros de Castro, 1998). However, it should be stressed that none of these categories can be treated as being "self-evident" (see Pina Cabral, 2014). The aim of this essay is in this regard that undoing any assumption of self-evidence by showing how these categories become semantically and practically destabilized after being applied to a specific interaction or case. 
are defined here as communicative acts — discursive or practical — that intuitively emulate the conceptual imagination and the formats of communication imputed to the counterpart. I shall argue that, in the context of a common struggle against the Earth's ecological crises, these mimicries highlight new forms of ecopolitical connectivity, and are harnessed to precisely overcome any assumption of pre-given ontological incommensurability. Ecopolitical translations will be addressed here as being produced, gestured or enacted by persons who, sharing the goal of protecting the Amazon rainforest, are invoking their particularly embodied histories, in order to effectively navigate the gap of the so-called equivocations.

The first part of the essay will briefly present the case of the scientist and the shaman public dialog, in order to promptly identify the specific interaction from which the following analytical questions will be raised. In the next two theoretical sections I will expose in more detail what I see as the analytical limitations of the notion of equivocation, showing its centrality for the ontological turn and in particular for the theory of perspectivism. Here I will ask what happens when equivocations are not only seen as recursive conceptual tools of and for anthropologists, but also as translational problems that the subjects we study can embody and re-translate themselves. With the aim of developing that question, in the following four sections, a case-centered look at the ecopolitical approximation between the shaman and the scientist will illustrate their equivocations and differences as well as their diplomatic efforts to navigate such translational gaps. I will propose the notion of 'ecopolitical mimicries' as a conceptual tool that might help to analyze these specific connective gestures as they are embodied by specific persons. In the last section, which is devised as a coda instead of conclusions, I will argue for the need to shift the analytical focus from ontological self-reflexivity to ecopolitical situatedness. This non-recursive turn relays on the perception that a too strong emphasis on the translational Self could blur the actual connections that different actors are drawing themselves in order to cooperate against current ecological crises.

\section{Setting the scene, raising some questions}

In 2010, the Brazilian climatologist Antonio Donato Nobre gave a TedX talk titled The Magic of the Amazon (Nobre, 2010a), in which the scientist elaborated on the climatological relevance of the Amazonian rainforest. Antonio Nobre is one of the supporters and developers of a new and controversial theory called the Biotic Pump (BPT), which suggests that the evaporation of forest 
trees may be a much more powerful driver of rainy winds than was previously assumed. In the middle of this talk, the scientist claimed that Amazonian indigenous views on the relation between rainfall patterns and the rainforest supported the BPT. Nobre explained that after attending a reading of a text by the Yanomami shaman Davi Kopenawa, he approached the shaman and asked: 'Davi, how did you know that if the forest is destroyed, there will be no more rain?'. To this, the shaman replied: 'The spirit of the forest told us'. According to Nobre, this insight surprised him because the Yanomami people had apparently already come 'to the same conclusion' that climate scientists were starting to develop now (Ibid).

For his part, the shaman Davi Kopenawa has struggled for the last two decades to bring Yanomami cosmology to the 'white people' (Kopenwa \& Albert, 2013: 133). Besides his activity as president of the Comissão-ProYanomami (Commission for the Yanomami People) and his numerous speeches given all over the world, an important part of this effort has been the release of the cosmological and ecopolitical manifesto The Falling Sky: Words of a Yanomami Shaman (Kopenawa and Albert, 2013). In this book, written with the help of his old friend, the anthropologist Bruce Albert, Kopenawa evokes in an autobiographical and detailed first person narrative his shamanic views on Yanomami cosmology, as well as his concerns regarding the social, economical and ecological danger in which the depredatory action of 'whites' has placed the Amazonian forest and its people.

Thus, on the one hand, the shaman Davi Kopenawa is assumed to be speaking from the point of view of a 'perspectival' or 'animistic' world of relations where the connections between persons, spirits and other beings are based on the premise of their shared humanity, while their disjunctions are given by their radically different bodily ,perspectives', which result in 'ontological' differences or 'differences of nature' (Viveiros de Castro, 1998; 2006). However, the shaman has shown an explicit willingness to write down in a book the terms by which what he calls Omama and the 'white people' call 'nature' or 'ecology' could work together (Kopenawa and Albert, 2013: 397, explained below in more detail). A first question to arise is therefore: Can a book-that is, a disembodied form of communication-explore and express cosmo-ecological differences and connections, as does the body of the shaman in the context of shamanic rituals? In other words: where is the shaman trying to get at in disembodying his knowledge in the form of a physical book? And why exactly is Davi Kopenawa, and not any other shaman, exploring the communicative potential of the written discourse? 
On the other hand, there is the natural scientist, a Brazilian climatologist with wellestablished research credentials, who pushes himself beyond the conceptual language of science. Antonio Nobre stands as one of the supporters of the ground-breaking Biotic Pump Theory (explained bellow). Seeking the support of the theory by the wider public, the scientist not only has quoted an Amazonian shaman to capture the attention of wider audiences; he has also claimed, during another presentation, his willingness to 'see' the forest and the climate 'with the eyes of the spirits' (Nobre, 2010b: 39). What sort of climatological 'seeing' is this? Is he not suggesting a desire to moving beyond his own naturalistic bodily perspective while adopting an animistic one? There is an obvious rhetorical intention in such an affirmation, but: is not the very staging of this affirmation, coming from a renowned naturalist, an invitation to further explore the current forms in which people from very different social and cultural contexts are trying to cooperate against the current ecological crisis?

\section{Perspectivism and the body}

In order to approach this case, I shall first propose an analytical frame based on a critical reading of the notion of translational 'equivocations' as it has been employed by ,perspectivism' and associated ontological theories (Viveiros de Castro, 2004). The theory of 'perspectivism', inserted two decades ago in the anthropological debates by the Amazonian anthropologists Tania Lima ([1995]1999) and Eduardo Viveiros de Castro ([1996]1998), has had great impact on the development of the ontological turn in anthropology (e.g., Holbraad, Pedersen and Viveiros de Castro, 2014). 'Perspectivism', along with its attached notion of 'multinaturalism', have fostered new analytical apparatuses where anthropological differences are reconsidered as being 'ontological' or differences of 'world' in contrast to the —relativist — 'epistemological' differences, or differences of 'knowledge' (Viveiros de Castro 1998). Roughly speaking, the combination of the notions of perspectivism and multinaturalism, emerging from Amazonian ethnographies but later adopted by scholars with other regional interests, has opened the possibility for questioning the (post)modernist equation of "one nature - many cultures", in order to propose a perspectival or multinaturalist inversion: 'one culture - many natures'. Such analytical inversion is made possible, according to its proponents, by abandoning the search of equivalences between conceptual languages in contact, and instead proposing an anthropology where analytical concepts emerge 
from and make sense solely within the 'worlds' or 'ontologies' of the people we study (see Holbraad and Viveiros de Castro, 2016).

I argue that one of the aspects that is often downplayed in the more recent ontological discussions is that perspectivism, as one of its central theories, stems from a specific Amerindian vision of the body as the place of difference, indeed a specifically Amazonian cosmological locus for the organization of intellectual and practical life (e.g. Erikson. 1996; Velthem, 2005; Karadimas, 2005; Viveiros de Castro et al., 2006; Overing, 2006). I also suggest that the assumption of translational incommensurability implicit in some readings of perspectivism fades when the theory abandons the 'metaphysical exotic'(Eckert, Glick-Schiller and Reyna, 2016: 321), in order to focus on specific ethnographic cases and embodied forms of interaction that claim for mutual inter-intelligibility.

In this regard, I find ethnographically clarifying Tania Lima's first formulation of the Amazonian notion of 'perspective' or 'point of view'. She explicitly disclosed there how personal pronouns signal the perspectival embodiment in Juruna language:

In my ethnographic material, the notion of point of view is indicated in a very simple way: the objective forms of personal pronouns receive the postposition be, 'to/for' ['para' in Portuguese](...). Thus, a sentence such as 'this is a tapir to me' simply means that the subject uses a particular meat in the same way another uses the tapir (Lima [1995]1999: 129)

In Juruna language neither the Self nor the Other relate to a 'tapir' properly, in a univocal sense. Self and Other share the idea of 'tapir', but their different points of view, i.e. their embodied perspectives, lead them to see and 'use' different types of meat as being the same: 'tapir'. As I understand the perspectival logic here, the theory makes the point that a concept such as 'tapir' does not designate a thing in particular, but a particular relation between two particular bodies. In other words, the relation 'tapir' (inasmuch as it can be seen as body-meat for feeding other bodies, for instance) always exists for two different beings (e.g. a Juruna person and a jaguar), but the tapir's meat will be different things depending on the kind of body that is eating it. Thus, from a Juruna's perspectival optic, a 'tapir' would be a specific relation between two bodies, an eating body (a Juruna person) and an edible body (tapir's meat): if the eating body would be substituted by another 
(for instance a jaguar eating instead of a Juruna person), the edible body would also necessarily need to be something else ', in order to still be 'tapir'3.

\section{Re-embodying equivocations}

While first perspectivist analysis addressed the way Amazonian cosmologies or conceptual languages divided the world and the relations between different beings and species, the theory soon took a recursive turn, by looking also -and mainly- at the perspectival disjunctions between the Amazonian natives and the very anthropologist's concepts. In order to overcome the alwaysimperfect search for equivalences between emic or native concepts and the anthropologist's concepts, Viveiros de Castro proposed a new 'method' of comparison that he termed 'controlled equivocation' (2004). This method was framed within a new theory of anthropological translation where the work of the translator was not oriented to find mutually corresponding concepts or words, but rather to show how to be aware of and analytically use-i.e. to 'control' - the ontological gap or equivocation existing between the anthropologist's concepts and an unreachable native's 'intentio [sic]' (2004: 5):

To translate is to situate oneself in the space of the equivocation and dwell there. Not to unmake it, since this would suppose it never existed, but precisely the opposite: to emphasize or potentialize it, that is, to open or widen the space imagined not to exist between the conceptual languages in contact (2004: 10)

A classic example of an equivocation is to be found in Lévi-Strauss Oviedo's history. If we follow Viveiros de Castro's reading of this episode (2004: 8-9), the body seems to be the first place of 'translational equivocations' between Amazonian and non-amazonian peoples. At the time of 'La Conquista', Spaniards were wondering whether indigenous peoples were humans - i.e. similar

\footnotetext{
${ }^{3}$ Viveiros de Castro has often illustrated this kind of perspectival, bodily disjunction with the example that in Amerindian positional terms what we mean by 'blood' is what a jaguar means by manioc 'beer' (e.g. 2004: 6). Hence jaguars drink manioc 'beer', from their own bodily perspective, when we see them leaking " 'blood' from our perspective.
} 
bodies with a different soul—or mere animals—i.e. only bodies without a soul; in return, indigenous peoples wondered whether Spaniards were people like them-i.e. different bodies with similar soul-or mere gods - i.e. souls without bodies. For anthropology, the equivocation originated in the fact that there were not two directly comparable notions of 'body' in Amerindian and Spaniards conceptual languages. While for the former the body could substantially (in nature) differ between beings, for the latter all living beings should have bodies of the same nature, but radically differ in having soul (humans) or not (animals).

The first assumption of perspectivist theory is that modern anthropological thinking has been colonized by a similar (yet perhaps more sophisticated) classificatory logic to the one expressed by Spaniards during la Conquista, hence leading us to equivocally reading the Amerindian body as a less elaborated or picturesque version of our own Wester-scientific notion of body-as-nature. The second and related assumption is that the 'control' of this equivocation would consist, according to Viveiros de Castro, in developing an anthropological comparison whose analytical concepts avoid collapsing the differences expressed in these conceptual languages, that is, the Amerindian idea of the 'body' as the place of essential (or 'ontologically radical') differences between beings (i.e. perspectivism, multinaturalism) and the European idea of the 'body' or nature as universal (i.e. naturalism).

The goal of the anthropologist as translator is, from such a standpoint, no longer that of finding culturally equivalent concepts, but rather that of disclosing how different are the relational 'worlds' or ontologies' that non-univocally related concepts address in different conceptual languages. In other words, the translative work operates here by expanding the knowledge about anthropological equivocations as a mode of comparison. The problem is that while the notion of " 'controlled equivocation', as I understand it, claims for a cautious comparison between imperfectly related conceptual languages, its attachment to the notion of 'radical difference' has introduced into it the rather implicit but not less provocative idea that different cultures or peoples are incommensurable (meaning completely equivocated about each other?), and that only the recursive analysis of the anthropologist as observer is to be theorized.

Such recursive gesture is surely necessary, yet formulated in the ontological turn terms also runs the risk of reifying the very 'ontology' of the anthropologist as observer or pole of comparison. This has given room to a number of mutual misunderstandings within the ontological debateincluding crossed accusations of conducting simplifying analyses (e.g. Viveiros de Castro, 2015; 
Graeber, 2015). My point is that the recursive turn of the idea of equivocation, despite its legitimate goal of opening us to self-critique, produces a certain sense of fixation, for instance in not (explicitly enough) disclosing how crucially important 'differences' operate within the social sphere of the anthropologists themselves (see Candea, 2011). This, I wish to argue, has alimented the straw man of ,incommensurability' between the anthropologist's world and the Other's world, limiting in the last instance the possibilities of disclosing how these worlds change, permeate each other, and vary internally as the result of their contact.

One of the possible diagnosis for this problematic is that the ontological debate has been displaced to an argumentative level dominated by philosophical a priori about de facto 'radically different' ontologies vs. actually 'entangled' realities. This is a level of abstraction where one indeed may loose the grip of what people, not anthropologists, actually do in their encounters, that is the situated forms of inter-action that are available to ethnographic inquiry. Accordingly, the critique I wish to present here is that, despite the great theoretical interest that the concept of equivocation might have for anthropological comparison, the relational situations in which ethnographers usually engage or observe today are driven by something more than pure metaphysical difference. As a general argument, I will suggest that the subjects we study do something more than confirming how equivocated are anthropologists when they try to translate among different cultures or peoples. While the radically different notions of 'body' of Spaniards and Amerindians could reveal the equivocated translations produced by colonial hermeneutics and anthropological metaphysics, it is worth noting not only that these equivocations might have been transformed since the time of La Conquista, but also that such transformations might be produced by the very subjects we study, in order to overcome old misunderstandings. For this reason, I propose to 're-embody equivocations' with the aim of shifting its recalcitrant emphasis on cosmological or metaphysical difference per se to an empirically situated account of how specific Amazonian actors embody and re-translate themselves these differences, turning them into 'connections' when there is a need to reach out to others (see examples in Rosengren, 2006; Santos-Granero, 2009).

This proposal needs the rephrasing of a particular perspectivist assumption originated in Amazonian ethnographies. It has been argued that the idea of 'embodiment', as famously put forward by Csordas, is not valid for the Amazon-Amerindian context, since in this cosmological setting the notion of 'body' does not correspond to a physical 'substance' wherein one can situate the 'Self' (Vilaça, 2005). Defined as 'point of view', the Amerindian 'Self' is a constantly shifting 
quality, a positional feature, that guides subjects' social behavior according to the logics of a SelfOther relation - hunter-prey, human-spirit, kin-enemy, etc. - and independently of any bodilysubstantiated perspective. I argue that this cosmological take on the 'body' might be constitutive of an Amerindian internal, indigenous sociology, but it does not reflect what these same peoples do when they want to diplomatically relate or reach out to 'non- Amerindians'. I suggest that specific persons might in fact resort to their own biography, their particular habitus or embodied history, as originally put by Bourdieu (1980), and find a personal connection there to those Others that are facing a related future of environmental collapse. Purely recursive or cosmological accounts of an ethnographic Self-Other difference become rather parametric if used to simply reject the threat that (what we call) climate change is posing to bodies as substances, selves or persons. In this regard, both the theory and the example brought to the fore in this article will show how the idea of embodiment may indeed help to analyze the ways in which particular persons, in specific situations, enact cosmological notions coming from relational modes such as the so-called 'perspectivism' and 'naturalism', and co-implicate them, in order produce a common ground for communication.

\section{On equivocated rainforests}

Since 2005, a group of microphysicists and climatologists have been developing the 'Biotic Pump Theory' (BPT), which has since its inception sparked intense controversy among atmospheric scientists (Gorshkov \& Makaraieva, 2007; Makaraieva et al., 2013). Unlike the widely accepted theory that holds that it is the Earth's rotation rate, the heating of the oceans, and atmospheric depth that are the main drivers of air masses, the BPT suggests that a more powerful driver of winds might be found in the biosphere, in particular in tropical forests. According to the BPT, the condensation of water vapour released by trees creates a rapid depression-a low-pressure zonethat powerfully attracts moist, high-pressure masses of air, which can be 'pumped' along thousands of kilometers, from oceans and seas towards the forest.

One of the supporters of the BPT is the climatologist Antonio Nobre who, in recent years, has not only defended it to his colleagues but has also intensively tried to communicate the climatological importance of the Amazonian rainforest to a wider audience, with the hope of affecting the debate around environmental policies on an international level (Nobre, 2009, 2010b). 
As I have already pointed out, one of the highlights of the scientist's struggle for popularizing the BPT was the TedX talk, The Magic of the Amazon (2010a) — with near a million views on the internet as of the time of writing, when he compared his scientific findings on the trees/rain relation with the ancestral knowledge of the Yanomami Shaman Davi Kopenawa. Allow me to recall that moment with more detail:

I'd like to tell you a short story. Once, about four years ago, I attended a declamation, of a text by Davi Kopenawa, a wise representative of the Yanomami people, and it went more or less like this: 'Doesn't the white man know that, if he destroys the forest, there will be no more rain? And that, if there's no more rain, there'll be nothing to drink, or to eat?' (...) This bugged me and I was befuddled. How could he know that? Some months later, I met him at another event and said, 'Davi, how did you know that if the forest was destroyed, there'd be no more rain?' He replied: 'The spirit of the forest told us.' For me, this was a game changer, a radical change. I said, 'Gosh! Why am I doing all this science to get to a conclusion that he already knows?' Then, something absolutely critical hit me, which is, seeing is believing. Out of sight, out of mind (...) I mean, we, Western society, which is becoming global, civilized - we need to see. If we don't see, we don't register the information. We live in ignorance (...) Davi Kopenawa doesn't need this. He has something already that I think I missed. I was educated by television. I think that I missed this, an ancestral record, a valuation of what I don't know, what I haven't seen. (Nobre, 2010a: 14:51-16:51).

The scientist went on to make an argument for 'turning the Hubble telescope upside down' (Ibid: 16:51), that is, towards the forest, so that we see its cosmic isomorphism as well as those properties of the biosphere that determine the dynamics of the atmosphere. He was right that Kopenawa does not need the Hubble to know about the relation between trees and rain. However, he was equivocal in presuming that Kopenawa, therefore, does not see that relation. On the contrary, Kopenawa has argued precisely that 'white people don't know the images of the rain being and his children. They probably think the water falls from the sky without reason! But me, I have often contemplated them in my dreams, like my elders saw them before me' (Kopenawa and Albert, 2013: 133). It is exactly by 'bringing down' images that shamans gather their knowledge; it is another way of seeing which is exclusive to shamans and constitutes the main technology for knowing their world (see Albert, 2014: 240).

Such observations seem to lead us back to the classic Spaniards-Amerindians equivocation of what 'bodies' are or can do. Antonio Nobre assumes that the ways in which shamans 'see' are 
identical to the ways in which scientists 'see'. What confounds the scientist is the naturalist attribution of having the same body abilities, and where he misses the point, at least from a perspectival standpoint, is in not being aware that shamans actually 'see' with an interior sight, i.e. 'with closed eyes' (see Villani et al., 2011), in the context of shamanic rituals and dreams.

If the body of the scientist and the shaman can be seen as places of translational equivocation, it is no less difficult to establish direct equivalences between their respective environmental concepts and images. It holds true, as Antonio Nobre suggests in his talk, that there are some conceptual parallels between what some climate scientists supporting the BPT and Amazonian shamans say about the relation between trees and rain. However, one may wonder whether these evident parallels are enough to claim that scientists and shamans have come 'to the same conclusion' (Nobre, 2010a). Here it is worth considering what Davi Kopenawa actually says about the relation between Amazonian trees and rain:

As soon as you cut down tall trees such as the wari mahi kapok trees and the hawari hi Brazil nut trees, the forest's soil becomes hard and hot. It is these big trees that make the rainwater come and keep it in the ground. The trees that white people plant, the mango trees, the coconut trees, the orange trees, and the cashew trees, they do not know how to call the rain. (Kopenawa \& Albert, 2013: 385).

Both the scientist and the shaman recognize that there is a relation between trees and rain, and that such a relation should pose certain limits to the human action on the Amazonian environment. But for all the apparent convergences, ${ }^{4}$ such a relation is strikingly different if we approach it from the shaman's or the scientist's perspective. By laying bare the physical causes and effects of microphysical systems on climate, the work of Nobre appears very different from the work of Kopenawa, who is negotiating with the sky through powerful xapirí-spirit beings (Ibid: 131-32). Further, it could be argued that it is not only the relation between trees and the rain they elicit that is different, but the very understanding of what an ['ecological'] relation actually is (Viveiros de Castro, 2013: 481).

\footnotetext{
${ }^{4}$ Bruce Albert points out in an endnote to the above-quoted passage that 'there is an interesting connection here with a recent theory that reveals the important effect of the tropical forest's 'pumping' atmospheric humidity has on the climate' (Kopenawa and Albert, 2013: 560).
} 
It is worth recalling at this point that the BPT suggests that the climatological relation occurring at the limits of the atmosphere-biosphere is thought of as being driven by the mechanism of a 'pump'. The metaphor selected here seems crucial, since it reflects plainly the 'naturalist' aspiration to a full 'mechanization of the world' (Descola, 1996: 97). The relation between trees and rain is likewise one of the issues at stake for the shaman, but the 'calling' of rain performed by some trees (Kopenawa \& Albert, 2013: 385) puts such a relation not in mechanistic terms but in an animistic -relational logic where non-human beings are endowed with human agency. Therefore, it is the concepts addressing the very nature of ecological relations that are different: trees and rain are indeed related for both the scientist and the shaman, but there is no conceptual agreement about what such a relation is made of.

Furthermore, the kind of environmental equivocations existing between the scientist and the shaman, and the distance between the 'worlds' they seem to 'represent' along perspectival lines of comparison, are also expressed in some misunderstandings about the very idea of the 'rainforest'. Thus, for instance, Gow regrets in his review of The Falling Sky the (English) translator's lack of elaboration on what Kopenawa is trying to get at with the word urihi, 'the forest': Yanomami urihi, Gow argues, 'is not the Yanomami equivalent of our notions of nature or the environment, but rather a livable world for Yanomami people' $(2014,305)$.

\section{Diplomatic translations}

However important it is to stress such differences of 'livable worlds', I argue that there is something more than translational equivocations to be addressed in Kopenawa's specific comparison of white and Yanomami environmental thinking. I suggest that the exploration of the ways in which these actors engage a conceptually dynamic space, where these same translational differences seem to be explicitly renegotiated for the sake of a meaningful dialogue is equally interesting:

When they speak about the forest, these white people often use another word: they call it 'environment'. This word is also not ours and until recently we did not know it either. For us, what the white people refer to in this way is what remains of the forest and land that were hurt by their machines (...) I don't like this word. The earth cannot be split apart as if the forest were just a leftover part. We are inhabitants of this forest, and if we cut apart this way, we know that we will die 
with it. I would prefer the white people to talk about 'nature' or 'ecology' as a whole thing (Kopenawa and Albert, 2013: 397).

Bruce Albert contextualizes the above-quoted passage in a series of endnotes where he discloses that Kopenawa's uneasiness refers to the double meaning of the Portuguese term meio (middle), which is part of the Portuguese word for 'environment', often referred to as meio ambiente. From a Yanomami perspective, meio suggests the violent division of the Earth 'into a center-the white people's world - and a subordinate periphery - the tropical forest conceived as a residual surrounding (environment) of that center' (Ibid: 562).

Thus, Kopenawa shows a clear rejection of the idea of meio ambiente as translation of urihi, for it contains the implicit notion of 'halving' the environment. For him, the rainforest is 'the entire world' (Ibid: 60) and should be 'understood as a whole' (397). However, the point I wish to make here is that he is not only disclosing an eco-cosmological difference with respect to what he assumes to be 'white people's' ways of conceiving of the 'environment' - with their tendency to analytically divide it into discrete units; he is also showing a translational indulgence towards other terms, such as 'nature', 'ecology' or even 'forest', which are likewise imperfect or equivocated, but which he is disposed to accept. In the above-quoted passage, Kopenawa scales up the parameters of comparison of the translation urihi-rainforest in order to leave more room, as it were, for other meanings to come inside urihi, and coexist.

I argue that the shaman is trying to diplomatically produce a space for conceptual negotiation where the co-implication of relational modes such as 'perspectivism' and 'naturalism' is made explicit. By co-implication I mean therefore in the first place the deliberate act by which apparently opposed perspectives are put in motion together by a specific social actor. Another central aspect of the co-implication of perspectives is that it needs explicitness in order to become an effective tool of communication. Such explicitness has then a diplomatic and even cosmopolitical sense, which is inspired by Stengers' observation that if there is no agreement about the cosmos, then diplomats must at least be able to establish 'explicit contrasts' (2005: 193). I would add that these contrasts should allow both sides of a cosmopolitical or, to be more precise, ecopolitical negotiation, to be aware of their differences as well as of their possibilities of cooperation. This is exactly the diplomatic intention I read in Kopenawa's point on the translational pair urihi-rainforest. In the following sections, I shall further explore how such contrasts are 
expressed and navigated through some mimetic gestures that put the scientist's and the shaman's bodies at the center of their strategic approximation.

\section{Extensive and intensive bodies}

In 2001 Antônio Donato Nobre gave a presentation about the biology of the forest to an indigenous audience in Manaus. He showed photographs and graphs, he recounts, because he knew the audience did not have any formal training in science. In the subsequent debate afterwards, an indigenous person stood up and angrily told him that:

Scientists think they know everything, but they know nothing. It's the Indians who possess the knowledge of the forest. Just because the scientists have satellites, they think they can see everything, but they see nothing, it's the eyes of the Indians through the eyes of the spirits, who see everything (cf. Nobre, 2010b: 38).

Nobre reported that, in trying to get to grips with this unexpected animosity, he took the microphone and appealed to the indigenous audience:

I started telling them about my paternal great-grandfather, Mané Nunes, who left an indigenous tribe in Minas Gerais and married my great grand-mother, who was black. The whiteness of my skin was the European dilution of my family, but it only came later. So, I'm proud of my native roots, and with $1 / 16$ th of indigenous blood in my veins, I felt myself to be kin of everyone in the auditorium. I went on to say that I had come in peace, and it didn't seem fair to be the subject of these attacks. (Ibid: 38-39).

Nobre continued with several quotes from Davi Kopenawa's foreword to the book Urih A: a terra floresta (Albert \& Milliken, 2009), trying to link Kopenawa's words about the life of the Amazon rainforest to recent scientific discoveries regarding the biology and biochemistry that were supporting the Biotic Pump Theory. Nobre suggests that his comparisons between indigenous knowledge and climate science, as well as the revelation of his 1/16 indigenous ancestry, aided in creating a better climate of conversation, since for that 'small group of people the ice between the two views of the world was broken' (Nobre, 2010b: 39). 
The scientist's 'diplomatic move' started with the elicitation of a distant but deep kinship connection with the indigenous audience. The invocation of his fraction of indigenous blood-plus another 1/16 of Afro-American lineage — was not only a way of relativizing the 'whiteness of [his] skin' (ibid) in the eyes of the indigenous audience, but also an analytical partition of his own body, aimed at destabilizing the scale of differences assumed by some people in the room. At least 1/8 of the scientist's body did not exactly fit, as it were, in what was assumed to be 'his world'. Furthermore, it was precisely this fraction of himself from which the scientist offered a new scalar frame for a negotiation of meaning.

I suggest that the fact of the scientist resorting to his $1 / 8$ of non-white ancestry, translated as a bodily substance-i.e. Indigenous and Afro-American 'blood', was flagged by Nobre as a sort of 'common ground' for a diplomatic encounter'. Moreover, I argue that this gesture sets up an interesting line of comparison with some gestures around the bodily-self performed by the shaman Davi Kopenawa. A recurrent theme in Amazonian anthropology is indeed the shamanic 'capacity to cross corporeal borders and to adopt the perspective of non-human beings' (Praet, 2009: 739). In working from the point of view of all kinds of beings that inhabit the forest and its surroundings, shamanism is said to operate as a sort of 'cosmic diplomacy' (Viveiros de Castro, 2006). In Kopenawa's case, the diplomatic art would consist of his ability to 'become other' (Kopenawa and Albert, 2013: 205-220), an ability which is mainly (trans)corporeal and that, as documented in other studies, makes shamans exceptional mediators not only with the beings of the forest, but also with the world of 'whites' (e.g. Vilaça, 2000; Kelly 2005).

It could then be said that both the scientist and the shaman experimentally elicit some nonevident qualities of their bodies in order to reach out to each other. Yet there are some important differences in these gestures of approximation that should be stressed. The most celebrated theoretical position from which anthropology has addressed such kinds of differences as they materialize in the Amazon region is perspectivism, and there is, in perspectival anthropology, the

\footnotetext{
5 It could be said that the trope of a distant ancestor who was indigenous is very widespread and regularly invoked in Brazilian constructions of identity. There is indeed a profound sense of the miscegenated identity of the Brazilian peoples, as masterfully explored by anthropologist Darcy Ribeiro (1995). This, to my view, makes still more crucial to ask why precisely in this nation, where racial and ethnic boundaries have been deconstructed both in theory and practice, has been the context in which the most radical accounts of ontological difference have been produced.
} 
implicit assumption that Deleuzian metaphysics - even though they were devised from within a Euro-American, non-perspectivist ontology — are the best tool to read the ways in which Amazonian peoples compose their worlds (e.g. Viveiros de Castro, 2010). This could be seen as an 'amazing historical coincidence', as sarcastically put by Laidlaw (2012). But leaving aside sarcasm, I would like to see what comes up from applying this language of comparison to the example at stakebefore I introduce my remarks in the next section.

To start with, while Nobre suggests he is in a deep level of his body an Indian, Kopenawa is in return very clear that he 'may become' but he is 'not a white man! [sic]' (Kopenawa and Albert, 2013: 206). The shaman's becoming-other happens after snuffing or drinking the yakoana powder; this brings him to a dimension of dreams in which he adopts the identities of one of the beings that populate his 'inner body' (Ibid 33 and Albert's note 23: 496). Kopenawa's becoming-other, through dreams and hallucinogens, seems therefore to be what in Deluzian metaphysics is called 'virtual', a 'virtual' that does not mean not-real -that is: opposed to the , 'real'-but opposed to the 'actual' (Deleuze, 1968: 269-70). In other words, in Kopenawa's context the 'becoming other' would be virtual in the sense that his internal multiplicity is in constant process of actualization, for the shaman has always the 'intrinsic ability to be something else' or 'infinitely differing from itself' (Viveiros de Castro, 2006: 324).

What the virtual aspect of the shamanic becoming-other tells us is not then that his diplomatic-bodily change happens in a dreamed or hallucinated 'world' as opposed to a real one. Rather, it tells us that the sorts of differences and relations that shamans deal with are what in a Deleuzian jargon are called 'intensive' (see Deleuze, 1968:286-335)': The virtuality or constant need of actualization of intensive differences originates in the metaphysical notion of intensity as a difference in itself, that is, a differential relation where the terms or the nature of the relation have not been previously given. If the extrapolation of Deleuzian metaphysics to anthropology is to be taken seriously, then it could be likewise accepted that shamanic transformation 'is less a case of

\footnotetext{
${ }^{6}$ It is worth noting that the use of 'intensity' as a metaphysical category dates back at least to Aristotle.
} However, I refer here to 'Deleuzian jargon' because is mostly the accounts of 'intensive' or 'extensive' differences by this philosopher that has become popularized in anthropology, especially in the work of Viveiros de Castro (e.g. 2010). 
(extensive) relations that vary [between things] than of (intensive) variations [within things] that relate' (Viveiros de Castro, 2010).

As far as we know from the ethnographic literature concerned, therefore, the cosmic diplomacy enacted by Kopenawa relates to a becoming-other that originates in the intensive differences existing within his body as potential triggers of shamanic transformation. Since these differences are 'intensive', they cannot be used to divide or fraction his body, as though it were a geometrical space or extension. The way shamanism conceptualizes the body is 'intensive' in the sense that its transformations involve whole changes of nature, and not divisions of a measurable extension (see Deleuze, 1968; Delanda, 2005a). In other words, when Kopenawa 'becomes other' it is his entire body or nature, not just a part of it, that is transformed into something else.

We have previously seen Kopenawa's explicit claim for considering urihi — the rainforest— 'as a whole', that is, as a non-fractionable entity (Kopenawa and Albert, 2013: 397). Such a cosmological principle is then likewise extendable to notions of the intensive and indivisible bodies of shamans as mediators between beings. This, one may argue with perspectival anthropology, is in clear contrast with the way in which the climatologist elicited a geometrical fractioning of his body with diplomatic goals. The climatologist's bodily differences were delimited in his body as extension, a physical space whose nature was one and remained therefore independent of the relation at stake. Following the Deleuzian-Amazonian-perspectival triad, we are hence invited to confirm the two radically different understandings of embodied difference and transformation: in the case of the scientist, 'extensive' differences that divide space, and the bodies within space, into discrete units that might be isolated and then recombined for enabling change; and in the case of the shaman, 'intensive' differences that have the potential to transform the body by an internally driven process of 'becoming other', in nature and as a 'whole' - rather than by its physical partition and recombination with fragments of other bodies.

\section{Experimental mimicries}

That said, it is now worth noting that this way of identifying 'radical differences' might be analytically useful, but it would benefit from being explicitly evoked as a mode of comparison based on changing and intermingling types, and not as a parametric anthropology whose 
'ontological' inferences cannot be transgressed and modified by the specific social actors it is set to study ${ }^{7}$. Even from a metaphysical perspective, 'intensive' and 'extensive' differences such as the ones evoked above, can only be understood in their co-implication. This is at least what I read in the remark that Deleuze posed to Bergson's too static separation of the 'extensive' differences of degree and the 'intensive' differences of nature (Deleuze, 1968: 308, see also De Landa, 2005b).

Furthermore, we have considered the body and the nature the climatologist deals with as being addressed through their 'extensive' properties, while the body and the world of the shaman have been approached as being driven by 'intensive' multiplicities. Yet we could also have considered the 'extensive' body of 'Kopenawa before being initiated' (Cesarino, 2015: 293). And likewise we could have emphasized that some fields of science, and in particular the kind of meteorological and climatological models with which Antonio Nobre works, are precisely driven by 'intensive' rather than 'extensive' data (De Landa, 2005a: 6) ${ }^{8}$.

There are at any rate different layers on which to explore the co-implication of intensive and extensive differences and, presumably also, to find out some entanglements of perspectival and naturalistic modes of relation. Yet what I am trying to focus on here is not the question of whether these different relational dimensions are a priori intermingled, either in science or in shamanism. Rather, I aim to explore such co-implication as it is experimentally produced and endlessly rephrased by the very social actors we are looking at. This involves drawing attention not so much to the mythological narratives or the philosophical and theological principles their discourses and

\footnotetext{
${ }^{7}$ I have here in mind the contrast between Descola's category of 'animism' as an analytical tool marking an ideal type of a mode of identification (2005), and Viveiros de Castro's animistic 'perspectivism', which sees a radical contrast — pre-analytical — between different ontologies or worlds to which the anthropologist should commit by taking either one side or the other (2013, see also Latour, 2009).

${ }^{8}$ In science, by intensive data are meant those unities that are not divisible without changing their internal nature, such as temperature or atmospheric pressure (whose quality is an intensive and non-divisible quantity), in contrast to extensive properties such as a volume or mass, whose division does not alter the internal structure of each resulting sample (their quality is an extensive and divisible quantity). Actually, it happens that some intensive properties are also the ratio of two or more extensive properties: e.g. density, which is an intense property, is the resulting ratio of mass and volume, which are two extensive properties
} (Ibid). 
actions are supposed to respond to, but to a confined set of breakthrough, explicit gestures. Following these lines, in the next pages I propose to analytically frame such gestures as 'experimental mimicries'.

The idea of 'mimesis' has already been employed in order to describe how in colonial times indigenous peoples imitated the behavior of invaders in order to deal with and even trick them (Taussig, 1993). More recently, 'mimetic empathy' has also been used to argue that the Yukaghir hunters of northern Siberia show 'the ability to put one's self imaginatively in the place of another, reproducing in one's own imagination the form of the Other's perspective' (Willerslev, 2004: 647). This mimetic empathy, Willerslev argues, allows hunters to conserve a 'double perspective': that of the hunter and that of the impersonated prey, and discloses how the perspectival 'becoming other' cannot be taken in any absolute sense when it is regarded against the practical life-worlds that ethnography describes (629-30). I suggest that this ability to reproduce 'in one's own imagination the form of the Other's perspective' has not only a practical side, but also an ecopolitical potential.

When Antonio Nobre claims that he would like to 'see' the forest and the climate 'with the eyes of the spirits' (2010b: 39), he is arguably not only expressing a willingness, but also signaling a disposition to adopt another perspective. He made it very clear when he invoked Davi Kopenawa's take on the relation between forest trees and rain (Nobre, 2010a). One may argue that he was just addressing the shaman's perspective in a metaphorical sense, as a rhetorical gesture. And indeed there is a deliberate staging in the way and the context in which the scientist makes such an affirmation. Yet the gesture remains still anthropologically relevant, to my view, insofar as it discloses a strategy of science communication where two discourses, that of science and that of shamanism, may 'resonate' in each other and thus gain 'mutual amplification' (Prigogine \& Stengers, 1984: 46).

So it would be unfair to simply neglect the ecopolitical potential of the scientist's allusion to the shaman. Nobre's project is that of producing a 'synthesis of knowledge' aiming at confronting the climatological future of the Amazonian region (2014). That means that with such a gesture the scientist is conserving his own naturalistic perspective - his synthesis is still of ,knowledge', that is epistemological, and therefore not of 'worlds', or ontological perspectives. But the gesture has nevertheless an ecopolitical and therefore anthropological interest, for it is built upon the recognition of the lack of knowledge about the Other - clearly expressed in Nobre's wondering: 'how could he know that?' (Nobre, 2010a: 14:51). This is why I will suggest next that the scientist's 
gesture should be addressed as being experimentally 'mimical', and not as a mere 'reference to', in as much as it displays a bodily disposition to navigate the anthropological distance with respect to the counterpart, without necessarily undoing such distance by means of an absolutely certain knowledge about how things work in the context Other, i.e. shamanism

In the first place, I want to make clear that the election of the idea of 'mimicry' aims at deliberately avoiding the incursion into the difference that Bourdieu (1980) saw between the oftenrelated concepts of 'mimesis' and 'imitation'. Exposed in his discussion about the idea of 'habitus', Bourdieu identified imitation as a reflexive process and mimesis as a mirroring that was not subject to consciousness (Bourdieu, 1980: 123). The kind of gesture I address here is however hardly amenable to either a closed dimension of conscious intentional imitation or a non-reflexive mimesis. Rather, a particular mixture of political intentionality and anthropological uncertainty seem to drive the scientist's connective gesture. This is why I do not see the scientist's mimetic gestures as collapsing differences or effectively closing the gap of translational equivocations. On the contrary, the awareness of an equivocation seems to be what constitutes the climatologist's disposition to adopt the regard of the 'spirits', in order to come as close as possible to the shaman's conceptual imagination. I would therefore situate this gesture in the terrain of a mimetic 'experiment': neither fully conscious nor totally unintentional, where the driver is precisely the willingness to cope with a certain gap of knowledge, without undoing it. The 'connection' is therefore not established by a reference, in the form of a complete knowledge about the counterpart -where the referrer assumes to know the referred without fissures; instead, the connection is intuitively mimicked, and indeed experimentally mise en scene, with the aim of 'exporting' a message to a anthropological domain yet to know.

On the other hand, the scientist seems to position himself in a non-orthodox perspective within the field of climate science. This is done not only by supporting a controversial theory, but also by exposing himself to a field of relations - e.g. popular science talks - that clearly overhauls the usual context of scientific discussions. This heterodox placement is in part executed by resorting to the notion of body — both his own body and the body in general—as a locus for expanding or communicating his environmental imagination. In his famous TedX talk, Nobre starts with a joke about his own body: 'I am a typical example of what [Sir Ken (another Ted speaker)] describes as 'the body as a form of transport for the head,' a university professor (2010a: 0:11)'. Immediately afterwards, he proceeds to critique the bodily analogies of the forest as 'lungs of the world', in 
order to rephrase it as the 'heart' that 'pumps' the atmosphere, with clear reference to the Biotic Pump Theory (ibid: 2:21-2:55). The body plays a central role in the way in which Nobre wants to communicate his environmental thinking to other people. And it could be further argued that such an ecopolitical opening is the result of a particular bodily 'disposition' of Antonio Nobre himself; that is, his particular habitus or 'embodied history' (Bourdieu, 1980: 111) - e.g. his 1/16 of indigenous blood, etc. I suggest that it is this particularly embodied version of a climate scientist, not climate science grosso modo, that impels him to reach out to other audiences and that enables ecopolitical negotiation.

On the other side is the shaman, Davi Kopenawa. His sky, hutukara, also has corporeal features - chest, feet, back - (e.g. Kopenawa \& Albert, 2013: 133). Furthermore, he clearly describes how the interaction with climatological phenomena always has the Yanomami's bodies as 'sensors' of the environmental hazards and the shamanic bodily performances as the responses to confront them (ibid: 137). There is an evident cosmological continuity between human bodies and the environment in Kopenawa's words. It is not surprising, for instance, that De Vienne writes apropos Kopenawa and The Falling Sky: 'when the body of the shaman has the same limits as the sky, his biography is a cosmography' (2014: 316). This is why throughout the book the reader has the impression that when Kopenawa speaks about himself and his body, he is also telling us something about the forest.

Yet Kopenawa does something more than, from a sheer perspectival or animistic point of view, compare his body to the forest's body according to their equal human agency and responsivity. He is also interested in "whites" disembodied forms of thinking. This is for instance how he compares Yanomami and "whites" modes of registering and transmitting knowledge:

This is why I want to send my words far away. They come from the spirits that stand by my side and are not copied from image skins I may have looked at. They are deep inside me. (...) Omama did not give us any books in which Teosi's words are drawn like the ones white people have. He fixed his words inside our bodies. But for the white people to hear them they must be drawn like their own, otherwise their thought remains empty. If these ancient words only come out of our mouths, they don't understand them and they instantly forget them (Kopenawa and Albert, 2013: 24).

I suggest that it is precisely because Kopenawa, as Nobre, is able to recognize the gap of the equivocation between embodied and disembodied forms of communication that he tries to navigate 
such distance by 'sending [his] words far away' and fixing them in 'image skins' (ibid), in a rather unconventional way from the vantage point of shamanic performances. This is also why in 2000 he held up, in the context of a shamanic ritual, the satellite image of the Earth's extension, the image of a planisphere (see Albert, 2014). This gesture destabilized the usual form of 'bringing down images' in conventional shamanic practices. That fixation of the image of the world in a rectangle of paper can be seen as an 'innovative form of political shamanism' (Ibid: 238), which aims at engaging or at least experimenting with the conceptual imagination and the communicative formats of whites.

These kinds of gestures are not mere spectacle, but potentially ground-breaking, mimetic incursions into the relational logics of the Other, which deserve some anthropological attention. As it has been already argued for the scientist, the shaman's gestures are likewise mimetic, because they depart from the recognition of an anthropological gap, and proceed by means of the intuitive emulation of the concepts and formats of communication imputed to the counterpart. Mimicry can be bodily and practical, as in the act of holding up the satellite image, or verbal, as for instance when Kopenawa called Antonio Nobre 'the Einstein of the Amazon'9. The shaman made this comparison to a journalist from Sao Paulo who was interviewing him with regard to the Yanomami territorial conflicts. This comparison was not taking place within a certain cultural context with a given pool of common referents, but precisely attempting to connect intuitively two different conceptual imaginaries. My interpretation is that Davi Kopenawa aimed at mimetically expressing his recognition towards someone from the context of the journalist - i.e. a 'white' scientist from the city of Sao Paulo - knowing that Einstein was a respected person in this context, but not necessarily knowing the stakes of Einstein's physical and cosmological theories.

The release of The Falling Sky is perhaps the best and most detailed example of what I mean by an 'ecopolitical mimicry'. The very process of recording, transcription and the later publication of The Falling Sky is illustrative of an experiment on ecopolitical connectivity conducted by the shaman with the complicity and support of the anthropologist Bruce Albert. The book in itself can be seen as a gesture - a remarkable disembodiment, which is anthropologically interesting due to the rupturing character that the writing down of thoughts involves for a shaman. For instance, Kopenawa clearly states in the book that the rainforest is 'urihi a, the forest-land, but also its image that can only be seen by shamans and that we call urihinari, the spirit of the

\footnotetext{
${ }^{9} \mathrm{http} / /$ terramagazine.terra.com.br/interna/0,,OI5437416-EI16863,00.html [accessed 02/06/2017]
} 
forest' (Kopenawa and Albert, 2013: 388). Then, one may wonder what is implied in the description of such an animated forest and its images in paper 'skins' (Ibid 24) - that is, writing it down in a book. As it has been said in an excellent review of the book, The Falling Sky rises the question of what does it mean the 'ontological debasement of the written discourse when compared with the original form of [shamanic] knowledge production and transmission (dreams, visions, accounts, and spirit-songs)'(Cesarino, 2014: 290).

According to Viveiros de Castro, The Falling Sky is actually 'a shamanic form in itself (...) in which a shaman speaks about spirits to whites, and equally about whites on the basis of spirits, and both these things through a white intermediary' (cf. Albert and Kopenawa, 2013: 448). In his introduction to the Portuguese translation, Viveiros de Castro (2015) points out the 'reaching out' aspect of Kopenawa's gesture, where he concedes that the book is an attempt to overcome the 'cosmological monolingüism'. I suggest that it is not only the content of the book, but also the book as disembodied materiality for communicating, that shows both the mimetic and the experimental aspect of such a gesture. A book is without any doubt a technology of the whites. At the beginning of The Falling Sky, Kopenawa tells the reader that he is putting his words down on 'paper skins' so that they - and the words of the xapiri — could travel to the world of the whites, far away, and propagate, in order to make them 'truly be heard', and 'penetrate the minds' of the whites (Ibid, 12). So the original words pronounced by the shaman may not have transgressed Yanomami shamanic conventions, but their translation, and their 'fixation' in geometric paper skins that will travel far away, reflects the shaman's intuition that the mimicry of alien formats of communication may aid to reach out to the imagination of those others yet to know.

\section{Coda. Situating ecopolitical translations}

Instead of asking what is the truly ontological question (as in metaphysics), this essay was initiated by asking what needs an ontological comparative tool such as 'translational equivocations' in order to adequately account for a particular situation of cross-cultural communication. The elaboration on whether 'worlds' are commensurable or not did not seem, in this regard, to be the best option to bring the here proposed anthropological critique far enough. Despite all controversies courted by the ontological turn, and besides the 'radical' and --most of all-- provocative quality of its 
conceptual tools, I still understand it as an extension of a rather classic and indeed very useful mode of anthropological critique, which has recently been labeled as 'genealogical': „Genealogy is interested in identifying what counts for true and false in a given world at a given moment (both concepts of perspective and picture not presupposing the existence of truth and falsehood but emphasizing power and language games between the two) (Fassin 2017:14).

Ontologically recursive anthropology has similar-wise proposed some theoretical tools that make sense of the worlds of the people we study, without pretending to equate their concepts and ours as the way to achieving a final truth or producing a neutral observation (see Holbraad and Viveiros de Castro, 2016). However, the comparison of 'their' concepts with 'our' concepts is, to my eyes, leading us to devote too much attention to the impact of the Other in our own scholarly, anthropological concepts, at the expense of a downplayed observation of how these others are actually transforming their own worlds and concepts. In recounting how he abandoned philosophy to 'become an ethnographer', Lévi-Strauss already noted the intellectual impoverishment he saw in taking metaphysical 'worlds' as the substance of a merely logical gymnastique (1955: 53). Much has been said afterwards, but the ontological superimposition of the anthropologist's Self and the world of the Other - even if it is for the sake of decolonizing our thought - still bears the hazard of practicing a kind of 'suprarationalism' where the first resigns precisely to her ethnographic sensibility (Ibid 61), that is her capacity to work inductively .

As I have shown in this article, ontologically self-reflexive positions are still providing inspiring analytical tools to the discipline, yet their omniscient anthropological Self may also pose some limitations to approach how the very natives of a climatic hot-spot such as the Amazon rainforest are currently re-negotiating their relationships and environmental concepts with the rest of the world. This level of negotiation is where the argument of the article has tried to dwell in. I have identified this form of public dialog around the rainforest as 'ecopolitics'. Thus, the main goal of this article has been to make some ontological questions into ecopolitical ones, in order to produce a theoretically unbound reading of a particular interaction between two particular persons.

I therefore suggest that 'ecopolitics' is still a crucial and urgent domain to be explored by anthropology. Eduardo Kohn (2016) has recently identified it as the 'going political' of what he calls 'sylvan thinking', i.e. a mode of ecological thought that he ascribes not only to forest's peoples as the Ecuadorian Runa, but to the forest itself. The notion of ecopolitics has indeed the potential to capture how local anthropological features play in the international arena. In a seminal article, more 
than two decades ago, Concklin and Graham (1995) already elaborated on the emerging Amazonian 'eco-politics' as the 'diverse arenas where Amazonian Indians and environmentally concerned outsiders interact' (695). Far from providing an enthusiastic view on what ecopolitical negotiations could bring to native Amazonian peoples, the authors identified many of its pitfalls. One of the critiques raised in that essay is particularly relevant for the topic of this article:

A second weakness in the Amazonian eco-Indian alliance is that it depends on a few individuals to mediate communications between local native communities and the outside world. (...) During the past decade, a remarkable group of indigenous cultural mediators has arisen. (...) these include Davi Yanomami, Ailton Krenak, Marcos Terena, Alvaro Tu- cano, Sia Kashinahua, and others. In outsiders' eyes, these individuals often serve as metonyms-symbols that stand for entire indigenous groups. Leaders come to be seen not as individual personalities but as representatives of an amorphous, homogeneous, authentic community. (704, my emphasis)

Davi Kopenawa - also known as Davi Yanomami — was then already in the eighties engaged in the ecopolitical struggle of the 'Amazonian Indians'. Furthermore, he was ecopolitically engaged as an individual, but an individual who was deemed to represent the Yanomami people to the 'outside world'. This is relevant in as much as Davi Kopenawa has likewise been approached anthropologically — not only by eco-activists — as the best exponent of Yanomami cosmology, in particular as the shamanic driver of the Yanomami 'cosmic diplomacy' (Viveiros de Castro, 2006). The question I wish to rise is whether a 'diplomat', from the vantage point of anthropology, can be seen as being representative of a given group. The answer is surely complex, since diplomats, as shamans, are very exceptional personalities. If I have suggested that Antonio Nobre and Davi Kopenawa are interesting figures to explore ecopolitically and not ontologically it is precisely because they are persons who, very much as diplomats, do not work from a representative center, but at the limits of their ontologies or worlds.

The position of a diplomat in a given ecopolitical negotiation is therefore ontologically liminal and also politically delicate. And as far as we know, diplomatic work always involves the assumption of a risk, which is defined by their effort to appear 'in front of other peoples with a new peace offering (...), to rephrase their requirements (...) [and with this] running the risk of being called unscrupulous traitors' (Latour, 2007: 20; see also Stengers, 2005: 193). This is why Nobre and other scientists involved in the Biotic Pump Theory are still facing the skepticism that the 
originality of the theory triggers among some of their colleagues ${ }^{10}$; and this is also the reason why Kopenawa is aware that his interest and openness to the world of whites have been used to accuse him of having 'become a white man' and 'not being a real Yanomami' (Kopenawa and Albert, 2013: 436).

The mimetic gestures I have presented here can be seen as the embodiment-or disembodiment, in the case of The Falling Sky - of these diplomatic risks in the persons of a shaman and a scientist. Their 'treason', it could be argued, is that of mimicking the concepts and formats of communication of their counterpart. However, such treason only makes sense if one assumes shamans and scientists should represent a given mode of being in the world, and that the active —and indeed militant - co-implication of their respective relational perspectives (i.e. perspectivism and naturalism) betrays some sort of ontological purity the anthropologist should not dare to contest.

Instead, I have tried to make clear that the defense of ontological purity was not helpful to address the particular interaction of the scientist and the shaman. With that aim, I have proposed to pay attention to an ecopolitical arena where the anthropologist's 'translational equivocations' are embodied and re-translated by the very subjects we study. Such connective gestures are, as I have shown, performed by specific and exceptional persons who devise innovative ways of communication to navigate their translational distance. Naturalism and perspectivism appear as being co-implicated on the stage, surely, to foster audiences's good feelings and empathy towards the need to protect the Amazon rainforest. The objection could be made that the here addressed public dialog is then a mere mise en scène; but equally true is that such an ecopolitical approximation is not necessarily more 'staged' than a shamanic performance, a scientific talk or an informant telling us solemnly what his or her world is made of. The central issue remains still the same: to observe what happens with anthropologist's equivocations when other people appropriate and navigate them, and propose the adequate tools to address these translational gestures in its full

10 The originality of the Biotic Pump Theory makes it indeed very attractive to the wider public, whilst is a focus of intense discussions and controversies among scientists of the field, as noted by an important editor (see http://blogs.bmj.com/bmj/2013/01/28/richard-smith-the-editor-thinks-yourpaper-is-nonsense-but-will-publish-anyway/). 
situatedness.

\section{Acknowledgment}

I want to deeply thank Antonia Walford for her insightful engagement with earlier versions of this paper, for her invaluable help with the materials that have made possible the approach to the Amazonian- climate science context, and for her theoretical challenges and suggestions in general. Without her, this essay would have never come into existence. Two fantastic anonymous reviewers and very perceptive editorial comments have also crucially contributed to improve the clarity of the argument. Many people in Barcelona, Bremen, London, Marburg, Rostock and Vienna have also commented and helped to redirect my thoughts on the here addressed topics. To all of them, my sincerest thanks.

\section{References}

Albert, B. 2014. Yanomami: Back to the Image(s). Paris: Fondation Cartier.

Albert, B \& Millken, W. 2009. Urihi A: A Terra-Floresta Yanomami. São Paulo: Instituto Socioambiental

Bessire, L. \& Bond, D. 2014. Ontological anthropology and the deferral of critique. American Ethnologist 41 (3): 440-56.

Bourdieu, P. (1980) Le sens pratique. Paris: Éditions Minuit

Cesarino, P. de N. 2014. Ontological conflicts and shamanistic speculations in Davi Kopenawa's The falling sky. Hau: Journal of Ethnographic Theory 4 (2): 289-95

Concklin, Beth A. and Graham, Laura (1995) The Shifting Middle Ground. Amazonian Indians and Eco-Politics. American Anthropologist, New Series, 97 (4):695-710.

Descola, P. (1996) Constructing natures. Symbolic ecology and social practice. In: Descola, P. and Pálsson, G. (eds.) Nature and Society. Anthropological Perspectives. London: Routledge .Pp. 82-102.

—(2005) Par-delà de la nature et culture. Paris: Gallimard. 
De Vienne, E. 2014. A Shamanic Bible and its Enunciation. Hau. Journal of Ethnographic Theory 4 (2): $311-317$

Deleuze, G (1968) Différence et Répétition. Paris: Presses Universitaires de France.

- (1981) Class on Spinoza, February 17, 1981. (Available online: http://www.webdeleuze.com/ php/texte.php?cle $=38 \&$ groupe $=$ Spinoza\&langue $=2$ [accessed 26.03.2016])

Fortun, K. 2014. From Latour to late industrialism. Hau: Journal of Ethnographic Theory 4 (1): 309-29.

Eckert, J., Glick-Schiller, N. and Reyna, S. (2016). Vision Statement. Anthropological Theory from and for Everybody. Anthropological Theory 16(2-3): 320-323

Erikson, P (1996) La griffe des aïeux. Marcage du corps et démarcages ethniques chez les matis d'Amazonie. Paris: Peeters.

De Landa, M. (2005a). Matter Matters. Domus Magazine. Issues 884 to 897

-2005b. Space: Extensive and Intensive. Actual and Virtual In: Buchannan I \& Lambert, G. (eds). Deleuze and Space. Edinburgh: Edinburg University Press. Pp: 80-88

Fassin, Didier. (2017) The Endurance of Critique. Anthropological Theory 17(1): 4-29

Feyerabend, P. (1962) Explanation, Reduction and Empiricism. In H. Feigl and G. Maxwell (ed.), Scientific Explanation, Space, and Time, (Minnesota Studies in the Philosophy of Science, Volume III), Minneapolis: University of Minneapolis Press, pp. 28-97.

Gow, P. (2014). 'Listen to me, listen to me, listen to me, listen to me . . ' A brief commentary on The falling sky by Davi Kopenawa and Bruce Albert. Hau: Journal of Ethnographic Theory 4 (2): $301-9$

Graeber, D. (2015). Radical alterity is just another way of saying 'reality': A reply to Eduardo Viveiros de Castro. Hau: Journal of ethnographic theory 5(2): 1-41

Hazarika, U. (2016) 'The Earth Can not Let Go of Us'. Analising Ontological Conflicts. Ethnos 1-20. DOI: $10.1080 / 00141844.2016 .1171791$

Holbraad, M. \& Viveiros de Castro, E (2016) Ideas of Savage Reason. Glass- Bead in Conversation with Martin Holbraad and Eduardo Viveiros de Castro. http://www.glass-bead.org/article/ ideas-of-savage-reason-glass-bead-in-conversation-with-martin-holbraad-and-eduardoviveiros-de-castro/?lang=enview [accessed on $24^{\text {th }}$ January 2017 ]. 
Holbraad, M. Pedersen. M \& Viveiros de Castro , E. (2014) The Politics of Ontology. Anthropological positions. Theorizing the Contemporary, (Cultural Anthropology website: https://culanth.org/fieldsights/462-the-politics-of-ontology-anthropological-positions

Hornborg, A. (2015). The Political Economy of Technofetishism: Agency, Amazonian Ontologies and Global Magic. Hau: Journal of Ethnographic Theory 5(1): 35-57

Kohn, Eduardo 2016. Ecopolitics. Cultural Anthropology. Theorizing the Contemporary, Cultural Anthropology website, January 21, 2016

Kuhn, T. (1962), The Structure of Scientific Revolutions, Chicago: University of Chicago Press. —2000, The Road Since Structure, J. Conant and J. Haugeland (eds.), Chicago: University of Chicago Press.

Laidlaw, James (2012) Ontologically Challenged. Anthropology of this Century, 4.

Lima, T.S. (1999) The two and its many: Reflections on perspectivism in a Tupi cosmology, Ethnos, $64: 1,107-131$

Karadimas, Dimitri (2005) La raison du corps. Ideologie du corps et representations de l'envioronnement chez les Miraña de l'amazonie colombien. Paris: Dudley, MA : Peeters.

Kelly, J. (2005). Notas para uma teoria do virar branco. Mana 11 (1)

Kopenawa, D \& Albert, B. (2013). The Falling Sky. Words of a Yanomami Shaman. Cambridge, Massachussets: The Belknap Press of Harvard University Press.

Latour, B. (2007). The recall of modernity. Anthropological approaches. Cultural Studies Review 13(1): $11-30$

_ (2009). Perspectivism: 'Type' or 'bomb'. Anthropology Today 25(2): 1-2.

Lévi-Strauss, C. 1955. Tristes Tropiques. Paris: Plon

Makarieva, AM. et al. (2013) Where do winds come from? A new theory on how water vapor condensation influences atmospheric pressure and dynamics. Atmospheric Chemistry and Physics, 13: 103956.

Makarieva A.M and Gorshkov V.G.,. (2007). Biotic pump of atmospheric moisture as driver of the hydrological cycle on land. Hydrology and Earth System Sciences, 11: 1013-33.

Nobre, A. D. (2009). REDD and PINC: A new policy framework to fund tropical forests as global 'eco-utilities'. In: Beyond Kyoto: Addressing the Challenges of Climate Change - Science Meets Industry, Policy and Public Volume: 8. 
— (2010a). The Magic of the Amazon: A River that flows invisibility all around us. TED Talk (video and transcript) (available online: https://www.ted.com/talks/ antonio donato nobre the magic of the amazon_a river that flows invisibly_all_around us/transcript [accessed on 8 April 2015])

-(2010b). Floresta e Clima. Saber Indígena e Ciência. In: Manejo do mundo: conhecimentos e práticas dos povos indígenas do Rio Negro, Noroeste amazônico. (Org.) A. Cabalzar, 38-45. Brasil: Instituto Socioambiental \& Federação das Organizações Indígenas do Rio Negro.

-(2014) The Future Climate of Amazonia. Sao Paulo: Edition ARA, CCST-INPE e INPA

Overing, J. (2006). O fétido odor da morte e os aromas da vida. Poética dos saberes e processo sensorial entre os Piaroa da Bacia do Orinoco. Revista de Antropologia 49(1):19-54.

Pina Cabral, J 2014. World. An Anthropological Examination. Hau. Journal of Ethnographic Theory. 4(1):49-73

Praet, I. (2009). Shamanism and ritual in South America: an inquiry into shape-shifting. Journal of the Royal Anthropological Institute 15: 737-54

Prigogine, I. \& Stengers, I. (1984) Order out of Chaos. Man's New Dialogue with Nature. New York: Bantam Books.

Ribeiro, Darcy (1995) O povo brasilero. Sao Paulo: Companhia das Letras

Rosengren, Dan - (2006) Mtsigenka Corporeality, a Nonbiological Reallity. Tipití. Journal of the Society for the Anthropology of

Lowland South America. 4(1-2): 81-102

Salmond, A. J. M. (2013) Transforming Translations (part I). 'the owner of these bones'. Hau: Journal of Ethnographic Theory 3 (3): 1-32

Santos-Granero, F. (2009). Hybrid bodyscapes: A visual history of Uanesha patterns of cultural change. Current Anthropology 50(4): 477-512.

Stengers, I. (2005) Introductory notes to an ecology of practice. Cultural Studies Review 11(1): $183-196$

Taussig, M. (1993) Mimesis and Alterity. A Particular History of the Senses. London: Routdglege.

Velthem, L. V (2005) Les mains, les yeux, le mouvement: les tressages des indiens au bresil. Bresil Indien: les arts des amerindiens du brésil. Donisete L. et al. (eds). Pp. 214-241. Paris: Edition de la Reunion des Musées Nationaux. 
Vigh, H. E. \& Sausdal D. B. (2014). From essence back to existence: Anthropology beyond the ontological turn. Anthropological Theory 14 (1): 49-73.

Vilaça, A. (2000). O que significa tornar-se Outro? Xamanismo e contato interétnico na Amazônia'. Revista Brasileira de Ciências Sociais, 15(44):56-72. 2000.

— (2005) Chronically Unstable Bodies. Some Reflections on Amazonian Corporealities. Journal of the Royal Anthropological Institute (N.S) 11: 445-464

Villani, Cedric et al. (2011) The Mathematician and the Shaman, With Closed Eyes. A Conversation between Cédric Villani, Davi Kopenawa, Bruce Albert, and Michel Cassé', in: Mathematics. A Beautiful Elsewhere. Paris: Fondation Cartier pour l'Art Contemporain, pp. 44-51.

Viveiros de Castro, Eduardo (1998) Cosmological Deixis and Amerindian Perspectivism. The Journal of the Royal Anthropological Institute 4 (3): 469- 488

-(2004). Perspectival Anthropology and the Method of Controlled Equivocation. Tipití: Journal of the Society of Lowland South-America 2(1): 3-22.

-(2006). A floresta de cristal: notas sobre a onotlogía dos espiritus amazonicos. Cadernos de Campo 14(15): 319-338.

- (2010a) Intensive Filiation and Demonic Aliance. In: Jensen C.B. \& Rodje, K. (eds) Deleuzian Intersections. Science, technology and Anthropology. Oxford: Berghahn Books. Pp. 219-54.

—(2010b) In Some Sense. Interdisciplinary Science Reviews. 35(3-4): 318-333

-(2013). The relative native. Hau: Journal of ethnographic Theory 3 (3): 473-502

-(2015). Who's afraid of the ontological wolf: Some comments on an ongoing anthropological debate. Cambridge Anthropology 33 (1): 2-17.

- (2015b). Prefacio. O Recado da Mata. In: Albert, B. and Kopenawa, D. A queda do céu. Palavras dum xama Yanomami. Sao Paulo: Companhia das Letras. Pp. 11-42.

Viveiros de Castro, E et al. (2006) Qu'est-ce qu'un corps? París: Flamarión

Willerslev, R (2004). Not animal, not 'not-animal'. Hunting, Imitation and the Empathetic Knowledge among the Siberian Yukaghirs. Journal of the Royal Anthropological Institute 10 (N.S.): $629-652$ 